\title{
Создание базы данных «Виртуальный гербарий ФГБОУ ВО Горно- Алтайского государственного университета»
}

\section{Creation of the database "Virtual herbarium Gorno-Altay state University"}

\author{
Папина О. Н., Хмелева И. Р. \\ Papina O. N., Chmeleva I. R. \\ Горно-Алтайский государственный университет, г. Горно-Алтайск, Pоссия. E-mail: degt1@таil.ru', hmeleva72i@mail.ru² \\ Gorno-Altay state University, Gormo-Altaisk, Russia
}

Peфepam. В Горно-Алтайском государственном университете начаты работы по созданию виртуального гербария путем оцифровки ресурсов гербарного фонда. Разрабатываемый курс позволит любому пользователю ознакомиться с состоянием флоры Республики Алтай.

Ключевые слова. Виртуальный гербарий, флора Горного Алтая, электронная база данных.

Summary. In Gorno-Altay state University works on the creation of Virtual Herbarium by digitizing the resources of the herbarium fund have been started. The developed course will allow any user to get acquainted with the state of the flora of the Republic of Altai.

Key words. Eelectronic database, flora of the Altai Mountains, Herbarium fund.

Глобальная задача сохранения биоразнообразия может быть решена на базе детальных знаний о разнообразии конкретных регионов. Биологи узнавали и узнают о существовании тех или иных растений в определенном регионе по коллекциям своих предшественников.

Гербарий используется для исследования морфологии растений, их экологической, географической и индивидуальной изменчивости, является главной основой для работы по систематике и, несомненно, останется таковым в будущем. Он документирует состав флоры той или иной территории распространение (ареал) видов, дает полные и надежные сведения об изменениях флоры той или иной страны за тот или иной период времени. Гербарный образец, собранный в качестве документации для одной работы, в дальнейшем становится их исходным материалом еще и для многих других исследований. По мере развития науки мы из одного и того же гербарного листа извлекаем все новую информацию, в то же время сохраняющийся образец всегда дает нам возможность проверить прежде сделанные заключения.

В настоящее время появляется необходимость в создании новых способов и методов, позволяющих значительно интенсифицировать и вывести на новый, более высокий уровень классические ботанические исследования (Кучерявенко, 2007). Для этого необходимо с каждым годом расширять информационное пространство ботанических исследований, базирующееся на локальных системах управления базами данных (СУБД) ботанических садов, единых информационно-поисковых системах (ИПС), таксономических базах данных, базах изображений. Создание виртуального гербария является одним из способов решения данной проблемы.

Компьютеры стали широко использоваться в ботанических исследованиях с середины 70-х гг. XX в. В начале 90-х гг. и в нашей стране началась достаточно бурная компьютеризация науки, и у многих ботаников появился серьезный интерес к созданию баз данных (Компьютерные ..., 1997) и использованию разнообразных численных методов обработки данных. Процесс этот ускорился с появлением новых коммуникативных возможностей, с развитием глобальной сети Интернет, где можно найти разнообразные базы данных по электронному гербарию. Они отличаются количеством хранимых видов 
растений, обзором территории, на которой эти растения распространены. В качестве примеров можно отметить гербарии Всероссийского института растениеводства им. Н. И. Вавилова , Центрального сибирского ботанического сада сибирского отделения Российской академии наук, Южного Урала, Московского государственного университета, Рязанского государственного университета им. С. А. Есенина, Гродненского государственного университета им. Купалы, Ботанического сада Ботанического института им. В. Л. Комарова РАН, редких и находящихся под угрозой исчезновения растений, произрастающих на территориях Великобритании.

Республика Алтай - один из уникальных регионов России. Географическое положение Горного Алтая, его климатические особенности, богатейшие запасы ценных видов растений, уникальный животный мир позволяют считать его одним из центров концентрации биологического разнообразия планеты.

Гербарий Горно-Алтайского государственного университета начал формироваться со времени образования этого учебного заведения (50-е гг. XX в.), базируясь на имеющихся гербарных материалах прошлых лет, т. е. он находится на стадии накопления коллекций. В настоящее время в гербарии насчитывается свыше 5000 гербарных листов. Имеются отделы - учебный, научный и исторический.

Студенты-биологи уже на первом курсе знакомятся с гербарием учебного фонда. На базе этого отдела читается курс лекций по анатомии, морфологии, физиологии и экологии растений, систематике низших и высших растений, фитоценологии, флоре и растительности Горного Алтая, луговедению, лекарственным и полезным растениям Горного Алтая, научным основам гербарного дела, интродукции растений Горного Алтая и т. д.

Фонд научного отдела гербария значительно пополнился за счет выполнения и защиты диссертационных работ сотрудников кафедры - это диссертации «Флора левобережья реки Катунь Онгудайского района (Республика Алтай)», «Флора лугов долин рек Катунь и Чуя (Республика Алтай)», «Орхидные Республики Алтай». В начале 2000 -х гг. в коллекцию поступили образцы в результате экспедиционных сборов с Центрального и Юго-Восточного Алтая под руководством И. М. Красноборова. Обучающиеся выполняют курсовые и дипломные работы по материалам учебных практик по ботанике, экспедиционных исследований флоры и растительности Республики Алтай и прилегающих территорий.

В данное время в научном отделе насчитывается около 1700 видов высших сосудистых растений, относящихся к 294 родам и 79 семействам.

По материалам научного гербария создана информационная система в виде флористической картотеки. На карточке по каждому виду выписаны с этикеток гербария все местонахождения и местообитания. Карточки объединены в том же порядке, как в коллекциях, и помещены в коробочки. Флористическая картотека имеет важное значение для детального картирования ареалов и помогает в изучении экологии видов и их адаптивных возможностей. Она пополняется при каждом новом поступлении материала в Гербарий.

В настоящее время нами идет работа по созданию электронной базы данных «Виртуальный гербарий ФГБОУ ВО ГАГУ». Преимущества автоматизированной базы данных в том, что она позволяет ботаникам всего мира дистанционно ознакомиться с уникальными экземплярами растений флоры Горного Алтая, контролировать состояние гербария: какие коллекции следует пополнять, какие виды могут быть предложены для обмена с другими Гербариями. Также можно использовать подобные базы для мониторинга за состоянием флоры Республики Алтай в связи с антропогенными воздействиями, для выявления хозяйственно ценных природных ресурсов, для охраны редких, исчезающих видов.

Нашей задачей было оцифровать гербарные образцы и составить электронную базу данных. Для получения файлов высокого разрешения гербарные образцы отсканированы. В качестве инструмента для разработки базы данных использован текстовый редактор html-страниц.

База данных состоит из главной страницы, представляющей собой список семейств, при нажатии на которые можно перейти на страницы, соответствующие каждому виду. Страницы представлены в виде таблиц. Индивидуальная страница вида содержит информацию об особенностях морфологии, экологии и распространении вида в Республике Алтай, а также фотографии гербарных образцов высокого разрешения (рис. 1). 


\section{ВИРТУАЛЬНЫЙ ГЕРБАРИЙ}

\section{ГОРНО-АЛТАЙСКОГО ГОСУДАРСТВЕННОГО УНИВЕРСИТЕТА}

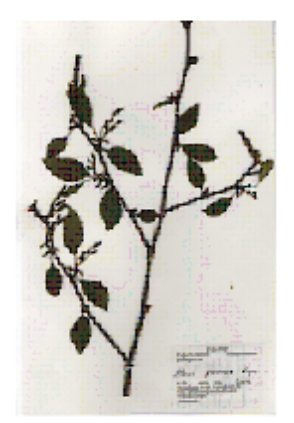

Duschekia fruficosa (Rupr.) Pouzдr - Oльховнгк ктст арвпковыг̆

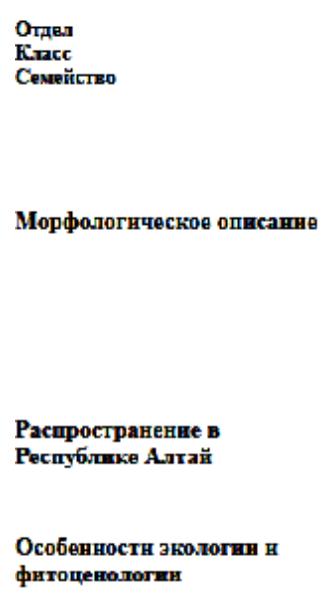

РЕКВИзНТЫ ВНДА

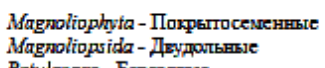

Кустарник, реже деревцг 2-6 м выс., однодознын, лвстопнднын, анемофильның. Кора темно-серая

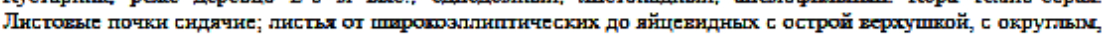

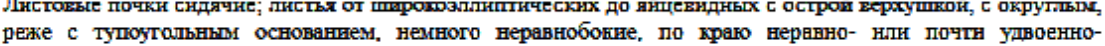

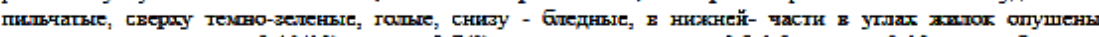
рыжеватьмн волоскамн, 5-10(12) см дл. н 3-7(9) см шир.. на терешках 0.5-1.5 см дл., с \&-12 парами боконых

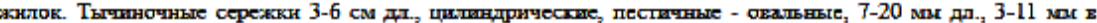

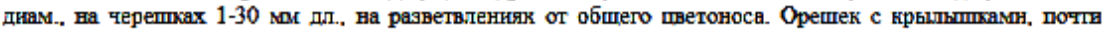

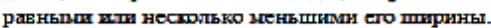

Ветречаетех в дол р. Маймы (окр. г. Горно-Алтайска), в дол. р. Көтуни (охр. с. Манхсрох), дол. рр. Бин (у

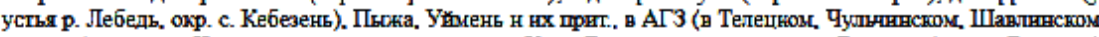

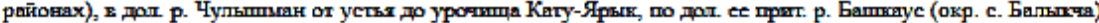
н по дог. ее прит р. Чебдар. на КУР (в дол. рр. Кубадру. Мангелу. Ник. н Верк. Ильдугем). КАТ (дол. р. Мулты). Цв. V-V]. П.. VIII-DX. Техн., тек

Растет (300-2250) в кедрово-лнственннчнык лесах, по берегам рек н ручьев, на гарях, вырубках, у дорог, ва

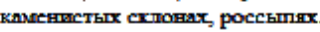

В каждом описании приведены авторские фотографии растений в природе и в культуре. Изображения всех растений можно увеличить, скопировать, распечатать.

Наибольшее количество информации приходится на семейство Ranunculaceae. В дальнейшем планируется заполнение БД по всем сборам научного гербария силами сотрудников и студентов кафедры биологии и химии.

Таким образом, традиционные и новые методики обработки ботанических данных в компьютерном варианте расширяют представления о возможностях интерпретации и установлении закономерностей в растительном мире, а также многократно повышают производительность научного труда исследователей-ботаников.

\section{ЛИТЕРАТУРА}

Компьютерные базы данных в ботанических исследованиях. Сборник научных трудов. // Под редакцией Д. В. Гельтмана, Ю. Р. Роскова. - Спб.: БИН РАН, 1997. - 113 с.

Кучерявенко О. А. Разработка базы данных электронного гербария: состояние вопроса // Вестник кибернетики, 2007, № 6. - С. 125-131. 